\title{
The Undead and Dark Tourism: Dracula Tourism in Romania
}

Duncan Light

This is an Accepted Manuscript of a book chapter published by Routledge in Dark Tourism: Practice and Interpretation on 14 July 2016, available online: (ISBN: 9781472452436; https://www.routledge.com/Dark-Tourism-Practice-and-interpretation/HooperLennon/p/book/9781472452436)

This work should be cited as:

Light, D. (2017) 'The undead and dark tourism: Dracula tourism in Romania', in G. Hooper and J.J. Lennon (eds) Dark Tourism: Practice and Interpretation, Routledge, Abingdon, $121-133$

\section{Introduction}

Although I have been researching Dracula tourism (the visiting of places in Transylvania associated with the Count Dracula of fiction and cinema) for more than a decade, I have not previously examined it in terms of dark tourism since, to my mind, there was little direct connection between such tourism and death or human suffering. However, conceptions of dark tourism are continually evolving and the phenomenon is now increasingly defined in terms of the 'macabre', meaning that dark tourism now embraces a wider range of sites and experiences which are not directly associated with death. I wish to begin this chapter by considering the changing definitions of dark tourism with particular reference to the notion of the macabre as a criterion for defining the phenomenon. I then want to examine Dracula tourism in Romania from the perspectives of both supply and demand. In terms of supply I argue that there is almost no deliberate provision of tourist experiences based on Dracula, so that identifying Dracula tourism as a form of dark tourism is problematic. When looking at demand, however, I argue that Dracula tourism is a heterogeneous phenomenon which encompasses a wide range of interests and expectations among tourists. 


\section{The Changing Scope of Dark Tourism}

Early definitions of dark tourism defined the phenomenon as 'the presentation and consumption (by visitors) of real and commodified death and disaster sites'. ${ }^{1}$ Similarly, the related concept of thanatourism was defined as 'travel to a location wholly, or partially, motivated by the desire for actual or symbolic encounters with death, particularly, but not exclusively, violent death'. ${ }^{2}$ As many others have pointed out, these two concepts had different emphases: dark tourism was defined by a supply-led perspective, whilst thanatourism adopted a demand-led approach. ${ }^{3}$ However, both definitions placed death - in particular, human death - squarely at the centre of this form of tourism. However, more recent conceptions of dark tourism (although not thanatourism) are rather broader. One influential definition states that dark tourism is 'the act of travel to sites associated with death, suffering and the seemingly macabre'. This raises the question of how dark tourism (hitherto focused quite specifically on death) has now come to embrace the 'seemingly macabre'? This change in scope seems to have been a response to various 'strange' or unusual forms of tourism (most notably, Gunther von Hagens' 'Body Worlds' exhibition) that are less directly connected with death, and which do not fit easily into existing typologies or definitions of dark tourism. ${ }^{5}$ Presumably it is the associations with the macabre that have lead recently to Dracula tourism being considered as a form of dark tourism. However, since Dracula tourism does not fit easily into Seaton's typology of thanatourism sites, it has not been identified as a form of thanatourism. ${ }^{6}$

The Oxford English Dictionary defines 'macabre' as 'grim, horrific or repulsive'. Clearly many places/sites with such properties are directly associated with death. However this is not always the case: some places that are labelled as dark tourism sites are not especially grim or horrific and have few direct associations with death. Examples might include parks of communist-era statues in Central/Eastern Europe; active volcanoes; Cold 
War nuclear bunkers; decommissioned nuclear power stations; the birthplaces of communist leaders, and sites of weapons testing. ${ }^{8}$ The macabre is especially problematic because it is a normative judgement with implicit overtones of aberrance, deviance and transgression: that which is macabre somehow flouts social norms. This links to Seaton's argument that the very term 'dark tourism' is a judgement based on an implicit contrast with 'light tourism'. ${ }^{9}$ In addition, the 'macabre' is a social construction, so that its meaning is culturally and individually relative, rather than absolute. ${ }^{10}$ The macabre will of course mean different things to different people, and that which societies deem to be macabre varies considerably over time and space. As such, labelling something as macabre (and consequently, dark) is 'a complicated matter of perspective and privilege'. ${ }^{11}$

As the scope of dark tourism continues to broaden almost anything that is somehow associated with death (or the macabre) is now being considered as dark tourism. ${ }^{12}$ Indeed, some recent conceptualisations of the topic have argued that dark tourism need not include death at all! ${ }^{13}$ Consequently, Sharpley has argued that 'such is the variety of sites, attractions and experiences now falling under the collective umbrella of dark tourism that the meaning of the term has become increasingly diluted and fuzzy'. ${ }^{14}$ This leaves dark tourism open to the criticism that the term fails to differentiate between very different types of site, based on very different associations with death, and offering completely different experiences to visitors. ${ }^{15}$ In response, various models have attempted to clarify the highly variegated nature of dark tourism. Stone proposes a spectrum of dark tourism supply, ranging from the darkest sites (sites of death or suffering with a predominantly educational orientation) to the lightest sites (those which are associated with, or represent, death or suffering and which are orientated predominantly around entertainment). ${ }^{16}$ Dracula tourism is implicitly identified as one example of 'lightest dark tourism'. ${ }^{17}$ While this model is useful for differentiating dark tourism provision (and the intentions behind such provision) it does not consider the 
experiences of visitors to dark attractions and the extent to which an encounter with death shapes their reasons for visiting.

Sharpley has also sought to clarify the nature of dark tourism by proposing a model which identifies four 'shades' of dark tourism. ${ }^{18}$ These are based on the nature of supply (accidental or purposeful) and demand (the extent to which visitors are seeking an encounter with death). This is important in recognising that both the supply of, and demand for, dark tourism are extremely heterogeneous, and it also acknowledges that tourists may have a wide range of reasons for visiting dark tourism places. However, it is widely recognised that the whole issue of why people visit dark tourism attractions is currently poorly understood. Moreover, there is a growing acceptance that not everyone who visits such places does so from an interest in death (or the macabre), ${ }^{19}$ meaning that many of the people at so-called dark attractions may not, in fact, be dark tourists. ${ }^{20}$ To better understand dark tourism there is, therefore, a need to look in detail at the motivations, expectations, experiences and practices of the tourists who participate in it. In particular, there is a need to engage with how such motives and experiences differ between different types of dark tourism attraction, but also within an individual attraction. ${ }^{21}$

\section{The Dark in Dracula Tourism}

In terms of supply, there is little attempt in Romania to provide attractions or experiences for Dracula tourists. Romania has long been reluctant to cater for Dracula tourism since the associations with vampires and the supernatural fundamentally collide with Romania's sense of its cultural and political identity. ${ }^{22}$ Consequently, for more than 40 years Dracula has barely featured in Romania's state-sponsored tourism promotion. Instead, the country has emphasised other forms of tourism in Transylvania such as cultural and heritage tourism, 
mountain tourism and, more recently, ecotourism/wildlife tourism, outdoor activities and culinary tourism. The state's approach to Dracula tourism has been to tolerate rather than encourage this form of demand. ${ }^{23}$

Consequently, the places in Transylvania that are mentioned in Bram Stoker's novel can all be visited by Dracula enthusiasts but most have made no attempt to cater for their interest. For almost five decades Dracula tourists have sought Castle Dracula, but since the castle never existed outside Stoker's imagination their searches have been in vain. This proved not to be a deterrent since another Transylvanian castle - Bran Castle - was quickly appropriated as Castle Dracula (see Figure 1). However, Bran has no connection with the fictional Castle Dracula (and is situated 150 miles south of where Stoker placed the castle) and does not feature in any of the Dracula films. However, as an imposing collection of spires and turrets, situated on a hill top, and located in Transylvania, Bran Castle looked right. Consequently it was quickly labelled by Western tourists as 'Dracula's Castle' and became, and remains, one of the major sites of Dracula tourism in Romania. That said, the castle's managers have never done anything to encourage the association with Dracula. Indeed, since opening as a visitor attraction in 1957 the building has been presented as a museum of medieval art, and more recently as a royal holiday home, although outside the castle a thriving market in horror-related souvenirs has now developed, and a private entrepreneur has opened a 'Castle of Horror' (a small indoor attraction which offers a short experience of a recreated haunted castle).

Figure 1: Bran Castle, Southern Transylvania

Elsewhere in Transylvania a hotel (now called Hotel Castle Dracula) was constructed in the 1980s in the approximate part of the Carpathians where Bram Stoker placed his 
fictional Castle Dracula. The hotel vaguely resembles a castle and includes a tower, crenelated walls, and an interior courtyard, while the reception and dining areas feature dark wood panelling and stuffed animal heads in an attempt to recreate the ambiance of spooky Gothicism. The hotel's managers have also established a crypt in an underground room which tourists can visit for a small fee, and which features vaguely macabre wall paintings (inspired by Dracula films), and a coffin in the middle of the room. A bored hotel employee recites the story of Dracula and his brides and then unexpectedly turns out the lights, whereupon another figure leaps from the coffin, generally producing shrieks from visitors. This is certainly an attempt by the hotel to produce a commodified experience, based on horror and the macabre, although there is not much else in the hotel that is macabre, and I am not convinced that an (optional) experience which lasts for less than five minutes makes the hotel a site of dark tourism. In short, there is little deliberate provision of Dracula-related experiences in Transylvania so that, in terms of supply, identifying Dracula tourism as a form of dark tourism is problematic. Only Bran's 'Castle of Horror' and Hotel Castle Dracula's short crypt experience are commodified representations of the macabre that could explicitly be identified as forms of 'lighter' dark tourism supply. For the most part, Dracula tourists have to make do with the dramatic landscapes of Transylvania or (as I argue later) make their own experiences of Dracula by using their imaginations.

In terms of demand, Dracula tourists are not a homogeneous group. Instead, Dracula tourism embraces a range of interests and motives, each associated with different degrees of interest in the dark and macabre (and sometimes no interest at all). One of the longest established motives for visiting Romania is a search for the literary roots of Bram Stoker's Dracula. The novel created a powerful place myth of Transylvania as 'one of the wildest and least known portions of Europe'. ${ }^{24}$ Stoker's Transylvania is a remote, sinister and frightful place, untouched by Western science and rationality, and where vampires roam freely. Stoker 
portrayed Transylvania as recognisably European (Count Dracula is, after all, a Hungarian aristocrat who speaks fluent German), but at the same time sufficiently different (and horrifying) to be threatening to the 'civilised' West. Transylvania has long attracted fans of Gothic fiction - and Dracula in particular - wanting to see for themselves the landscapes and settings of the novel, an activity which can be understood as a form of literary pilgrimage. ${ }^{25}$ For example the British 'Dracula Society’ has visited Transylvania regularly since 1974, while many other fans have made individual visits or have joined organised tours to the region. Several of the tourists that I interviewed on one Halloween tour to Transylvania explicitly spoke of wanting to follow in the footsteps of Jonathan Harker (an Englishman who journeys to Castle Dracula in the early part of Stoker's novel). However, literary tourists are themselves a diverse group and are not confined to fans of Dracula. The broader genre of vampire fiction has enjoyed extraordinary popularity in recent decades and although many of these novels do not mention Transylvania, the region has an established reputation as the seemingly natural home of vampires. This, in turn, draws enthusiasts wanting to see Transylvania for themselves. Another type of literary tourist are those seeking inspiration for their own writing; on the Halloween tour that I joined two of the twenty-one participants were intending to write their own vampire novels and were visiting Transylvania to gain local knowledge and colour.

Is there anything about such literature-based Dracula tourism that constitutes dark tourism? After all, the rather earnest motives assumed of literary tourists seem far removed from the 'lighter dark tourism' of which Dracula tourism is apparently an example. There is certainly plenty about death in Bram Stoker's Dracula: Count Dracula has many victims among the Transylvanian (and British) population and meets his own death at Castle Dracula at the end of the novel. More broadly, a visit to Transylvania is underpinned by the absent presence of Count Dracula, himself a monstrous (and macabre) figure. In this sense literary 
tourism in Transylvania could be loosely considered as tourism based on death and the macabre. This, however, raises the question of whether dark tourism can embrace death that has taken place in fiction. Some authors find this unproblematic and in his discussion of 'dark fun factories' Stone argues that fictional death can be the basis for dark tourism experiences. ${ }^{26}$ However, I am not convinced: in my view to include death that is represented in fiction under the umbrella of dark tourism rather stretches the concept beyond its limits. In any case, I suspect that many Dracula tourists seeking the literary origins of Dracula are more interested in the dramatic landscapes of the region and in particular the setting of Castle Dracula, rather than Dracula's (fictional) death.

A second, related, form of Dracula tourism is the desire to see a place - Transylvania - that has previously been encountered through film. This can be considered as a form of film-induced tourism (although since more people have encountered Dracula films on television, the term 'screen tourism' is perhaps more appropriate). ${ }^{27}$ More than 350 films have been made about Count Dracula and most feature Transylvania in some way. Screen tourists (like literary tourists) are drawn to the place myth of Transylvania, but especially to the sinister and terrifying Castle Dracula situated high in the Carpathian Mountains. A wellestablished characteristic of screen tourism is that tourists seek the location that is represented in a film rather than the location where filming actually took place. ${ }^{28}$ None of the major Dracula films were made in Transylvania (and Hammer Studios famously used woodlands near its Berkshire base to represent the forests of Transylvania). Nevertheless, screen tourists are eager to see for themselves the places in Transylvania portrayed in the Dracula films.

Both literary and screen Dracula tourists are seeking an encounter (albeit a lighthearted one) with the horror of the Dracula story. In this, there are clear parallels between Dracula tourism and what has been termed 'Gothic tourism'. ${ }^{29}$ This involves tourism experiences which are about engaging with (and are underpinned by) the tropes and 
discourses of Gothic fiction. It is a ludic form of tourism with a strong affective dimension based on horror, dread, thrills, frights and a delight in the uncanny and unknown. In particular, Gothic tourism involves a theatrical delight in creating or entering imaginary (or imaginative) worlds. Certainly, for many screen (and literary) tourists a visit to Transylvania includes a strong imaginative and playful component. Being in a location portrayed in a film is an opportunity to suspend disbelief and 'connect' with the imaginative world of that film through engaging in fantasy, escape and dreamwork. For example, Dracula tourists may hope to encounter Count Dracula (in some form) during their visit to Transylvania. At Hotel Castle Dracula some enthusiasts that I interviewed went outside on solitary searches for bats or wolves. ${ }^{30}$ When visiting film locations, tourists often engage in imaginative play by reenacting iconic scenes from the film itself. ${ }^{31}$ This is quite common among Dracula tourists: at Bran Castle, visitors often play at being Dracula, adopting the classic stance of arms aloft ready to pounce on a victim and intoning lines from the film. ${ }^{32}$ Others hide behind doors or furniture and leap out on their family or friends with a blood-curdling shriek. In a variety of ways, tourists enchant their visit through blurring the boundary between the real and the imaginary.

Does any of this represent a form of dark tourism? A visit to a place associated with a horror film may be motivated by a desire to connect with something 'dark' (such as the castle where Count Dracula met his death). And without question some screen (and literary) tourists are seeking an experience based on terror and dread when they visit either Bran Castle or Hotel Castle Dracula. However, this is quite different from entertainment-based dark tourism experiences where, for example, horror or death is represented in front of visitors. Instead, the horror in Dracula tourism is something that visitors have to make for themselves, based on what they bring with them from home, and by giving free reign to their imaginations. ${ }^{33}$ Moreover, while such experiences may appear to be based on horror, those who take part do 
not appear to find them horrific (in contrast to entertainment-based representations of death and suffering). This illustrates the difficulties of using the 'macabre' as a criterion for defining Dracula tourism. The macabre means very different things to different people in different circumstances: those activities which observers may judge as rooted in the macabre may not be considered in such terms by the people taking part.

A further group of Dracula tourists (some of whom are also literary or screen tourists) are those drawn to the supernatural roots of the Dracula story. Transylvania is inextricably associated with vampires in Western popular culture (even though vampires are unknown in Romanian folklore), which is why some tourists are seeking an encounter with the supernatural during their visit. Transylvania is not an isolated case: the supernatural (and ghosts in particular) has long fascinated tourists. ${ }^{34}$ Indeed, Bristow and Newman propose something called 'fright tourism' as a specific form of dark tourism/thanatourism. ${ }^{35} \mathrm{Such}$ fright tourism usually involves encounters with ghosts and the supernatural and offers experiences that are scary and thrilling but which (unlike risk recreation or adventure tourism) do not involve actual danger. Related phenomena include 'ghost tourism, ${ }^{36}$, 'spook tourism, ${ }^{37}$ and 'haunting tourism, 38 .

Certainly there are a number of locations around the world that have a healthy tourism industry based on their associations with the supernatural and otherworldly. For example, Scotland has long attracted visitors in search of ghosts, spooks and phantoms; indeed, ghosts feature prominently in the country's tourism promotion. ${ }^{39}$ Numerous cities throughout the world now offer ghost walks. ${ }^{40}$ In particular, New Orleans has long appealed to tourists on account of its associations with the supernatural and occult. ${ }^{41}$ The city offers visitors a range of guided walking tours themed around ghosts, cemeteries, Voodoo and vampires. ${ }^{42}$ Similarly, Salem in Massachusetts now attracts over a million visitors a year due to the Salem witch trials of 1692 after which 20 people were executed for witchcraft. There are also places 
outside Romania that draw tourists because of their Dracula associations. The best example is Whitby in Yorkshire which offers a 'Dracula Experience' attraction and Dracula-themed walking tours. Since 1994 the town has also hosted Gothic festivals (in April and at Halloween) and the associations with Dracula and the spooky are increasingly prominent in the town's tourism marketing. ${ }^{43}$

Around half of the group on the Dracula tour I accompanied stated that they had some sort of interest in the supernatural. But the nature of this interest varied considerably and most simply enjoyed the supernatural as entertainment: their interest was in the pop culture vampire rather than in the occult. For example, one Australian tourist argued: 'I think everyone on this tour...has come onto it because they love vampire fiction, not because they believe vampires exist'. An American tourist (who was a committed Christian) stressed that her interest in the supernatural was 'purely entertainment, you know what I mean; it's a little fantasy world and it's entertainment and, you know, it's fun'. Another visitor from America explained: 'I'm into horror and spooky stuff, I love being scared' but she emphasised that it was all about fun. A Canadian visitor put it more bluntly: 'I would never come on this trip if I actually believed [in the supernatural]'.

Central to the enjoyment of the supernatural as entertainment is the affective thrill of being 'spooked'. This involves a playful willingness to give freedom to the imagination and delight in the possibilities of the unknown and ineffable. It is an experience based on 'a reflective self-awareness of delusion and make-believe...a willing and deliberate suspension of disbelief. ${ }^{44}$ Another important aspect of being 'spooked', however, is a sense of fear and apprehension of that which is not known: vampires, ghosts and other supernatural creatures. At the same time this fear is mediated by the knowledge that the danger is not real and poses no actual threat. This was expressed by a Canadian visitor who said: 'I'm an atheist...so I really don't believe in anything that goes bump in the night... I don't believe in it [but] I 
enjoy it...fear,'. This illustrates how the encounter with the imaginary-supernatural can offer intense but controlled (and temporary) thrills, based on 'pretend' danger. ${ }^{45}$ Such 'delight without delusion ${ }^{46}$ involves only a suspension of normality and the tourist is confident that they will be able to return safely and without difficulty to the 'real' world. ${ }^{47}$

At first sight, it might appear straightforward to label anything involving the supernatural as macabre, and therefore an example of dark tourism. But again, those Dracula tourists who engaged in such ludic and light-hearted enjoyment of the "pop culture supernatural' may not consider it to be in any way macabre. The experience is again grounded in imaginative play and the enjoyment of what is unknown (searching for the monster when visiting Loch Ness might be another example). The success of the Harry Potter books and films testifies to the popularity of the supernatural-as-entertainment. And with its emphasis on thrill, controlled danger and an ultimate return to safety it could be argued that enjoyment of the pop culture supernatural has more in common with a rollercoaster ride than with dark tourism. Indeed, many theme parks feature rides (such as ghost trains or haunted houses) with distinctly gothic themes, and their users are probably concentrating more on fun and entertainment, than death or the macabre. ${ }^{48}$

However, other Dracula tourists have a deeper interest (and sometimes a sincere belief) in vampires and the supernatural. Once again, the nature of this interest varies considerably. On the tour I accompanied, one person was deeply curious about vampires and their reputation for immortality; another enjoyed reading about the supernatural but did not want to go further. Several others spoke of how the supernatural was important and meaningful to them. For example, one couple stated 'we're in touch with our dark side', while another claimed to have 'been an occultist ever since I was 12'. While these visitors were happy to enjoy the supernatural as entertainment along with the other visitors, what had brought them to Transylvania seemed to be a search for some sort of connection - and contact 
- with the supernatural. This was particularly the case at Halloween when the boundaries between the material and the spiritual worlds are believed to temporarily dissolve so that ghosts and other supernatural beings can reign more freely.

Such an interest in the supernatural might appear to be an unproblematic form of dark tourism on account of its associations with death and the macabre. Certainly some scholars have no difficulty in accepting travel to places associated with 'other', New Age or pagan spiritualities under the umbrella of dark tourism. ${ }^{49}$ However, I again argue that the situation is not so straightforward. Firstly, the word 'supernatural' is extremely wide-ranging, embracing anything and everything that transcends nature or scientific understanding. ${ }^{50}$ Even a more narrow definition of the supernatural which focuses on the occult or paranormal embraces a wide range of beliefs and practices. In terms of dark tourism, not everything associated with the supernatural has connections with death, and certainly some supernatural entities are very much alive. There are parallels with Sharpley's claim that many of the people who visit the graves of famous people are more interested in their lives than in their deaths. ${ }^{51}$

Furthermore, defining touristic interest in the supernatural as macabre is also problematic. As I argued earlier, the macabre is a normative judgement made from a particular standpoint. Certainly those tourists with an interest in the supernatural and occult would not necessary consider these topics to be macabre. In fact, for such tourists, a visit to Transylvania probably has more in common with religious/spiritual tourism than dark tourism. It is a journey based on spirituality: something which 'assumes the existence of the supernatural, though not necessarily a god or gods, and therefore represents a wider connotation of the sacred ${ }^{52}$ In particular, for some, the trip to Transylvania can be considered as a form of pilgrimage: travel redolent with meaning, to a place considered sacred within an individual's belief system, that is underpinned by a desire to connect with 
the Other. ${ }^{53}$ It is a journey which provides an opportunity for connection and transformation, but which can also be an occasion to discover or express a new (or 'real') sense of identity. ${ }^{54}$

\section{Conclusion}

In this chapter I have examined the relationship between Dracula tourism and dark tourism and have considered if it is appropriate to identify Dracula tourism as a form of dark tourism based on existing typologies and ways of classifying the subject. In terms of supply there is little basis for describing Dracula tourism (at least in Transylvania) as dark tourism. Romania has long been unwilling to cater for Dracula tourists and there is little provision in Transylvania of the commodified and entertainment-based experiences which constitute 'lighter dark tourism'. Bran Castle may be consumed as Castle Dracula by visitors but the site's managers have never done anything to encourage the association. Hotel Castle Dracula is intended to cater for Dracula enthusiasts but, with the exception of the short 'crypt experience', there is little about the site that is dark or macabre. However, Dracula tourism takes different forms in different places and at other locations on the Dracula trail particularly Whitby - there is more of a deliberate attempt to provide experiences for visitors based on death, horror and the macabre.

When looking at demand for Dracula tourism the situation is much more complex. I have identified three broad (but overlapping) motives for taking part in Dracula tourism: an interest in the literary, cinematic, and supernatural dimensions of the Dracula phenomenon. Within each of these groups there is considerable variation in the extent to which visitors are seeking an encounter with death or the macabre. Some literary/screen tourists may be drawn specifically to see the site of Dracula's death, although I suspect they are few in number. Most have broader motives: some are interested in seeing the places and landscapes - 
particularly Castle Dracula - represented in Bram Stoker's Dracula (and its many cinematic adaptations), while others are seeking an encounter with the Otherness of Transylvania as a wild, remote and sinister place. Their visit is underpinned by the tropes of Gothic horror, but these lead to experiences of thrill and delight rather than horror or repulsion.

A third group of Dracula tourists is those with an interest in the supernatural. Once again this group encompasses a broad range of interests and motivations. Some Dracula tourists have personal beliefs which embrace the supernatural and a visit to Transylvania on the Dracula trail is a form of pilgrimage which offers an opportunity for a connection with the otherworldly. But for many others the supernatural is simply a source of entertainment. A visit to Transylvania offers the prospect of thrills and delight in being spooked (and even frightened) by an encounter with the supernatural (characteristics shared by some literary/screen tourists). This might appear to be underpinned by the macabre but such engagement with the supernatural is an experience based on 'pretend' horror (in which thoughts of death may be entirely absent). For these participants such experiences are exciting rather than horrific, and for many Dracula tourists the boundaries between horror and play are very blurred. In short, the diversity of motivations and experiences among Dracula tourists in Transylvania mean that identifying it unequivocally as a form of dark tourism is problematic. It is possible to say that it may represent a form of dark tourism, for some tourists, for some of the time. This makes it the 'palest' form of dark tourism in Sharpley's formulation, involving tourists with a minimal interest in death, visiting places not intended as dark attractions. ${ }^{55}$

The underlying theme of this chapter has been the difficulties in defining what is (and is not) dark tourism. Existing typologies and classifications of dark tourism have sought to delimit dark tourism on the basis of 'what it is' or 'why is it provided?' or 'why do visitors go to dark sites?'. However all of these approaches have their weaknesses and none have been 
totally successful in defining the nature and scope of dark tourism. For this reason it is time to put such typologies to one side and consider dark tourism in new ways. Recent work has conceptualised dark tourism as a form of 'mortality mediation'. ${ }^{56}$ That is, dark tourism is one of a number of ways in which contemporary societies (and individuals within those societies) engage with and negotiate (absent) death. Thus dark tourism represents a form of filter (or contact point) between life and death which can help individuals to reflect on, and understand, mortality without fear or dread. This process can obviously unfold in a multitude of ways, but the key point is that this way of thinking moves the focus away from 'what is dark tourism?' to 'what does dark tourism do?'. This approach puts the emphasis on the cultural 'work' and meaning-making that is involved in dark tourism within contemporary societies. ${ }^{57}$ Considered from this perspective, Dracula tourism can be used to throw light on the playful negotiation of horror in leisure settings; the role of the imagination in the tourist experience; and the way that tourist practices reproduce myths about 'Other' places. In terms of dark tourism research, this is an opportunity to move the debate on from well-worn issues such as typologies, authenticity, commodification and ethics to put questions of performance, agency, ritual, play, identity and experience centre stage. ${ }^{58}$

\footnotetext{
1 Malcolm Foley and John J. Lennon, 'JFK and Dark Tourism: A fascination with assassination,' International Journal of Heritage Studies 2, no.4 (1996): 198.
}

2 A.V. Seaton, 'Guided by the Dark: From thanatopsis to thanatourism,' International Journal of Heritage Studies 2, no.4 (1996): 240.

${ }^{3}$ Tony Seaton, 'Thanatourism and its discontents: An appraisal of a decade's work with some future issues and directions,' in The Sage Handbook of Tourism Studies, ed. Tazim Jamal and Mike Robinson (London: Sage, 2009), 523. 
${ }^{4}$ Phillip Stone, 'A dark tourism spectrum: Towards a typology of death and macabre related tourist sites, attractions and exhibitions,' Tourism: An Interdisciplinary International Journal 54, no.2 (2006): 146.

${ }^{5}$ Phillip R. Stone, 'Dark tourism and the cadaveric carnival: Mediating life and death narratives at Gunther von Hagens' Body Worlds,' Current Issues in Tourism, 14 no.7 (2011): $685-701$.

${ }^{6}$ A.V. Seaton, 'War and thanatourism: Waterloo 1815-1914,' Annals of Tourism Research 26, no.1 (1999): 131.

${ }^{7}$ Oxford English Dictionary, www.oed.com (retrieved 15 May 2015)

${ }^{8}$ These examples were taken from www.dark-tourism,com (retrieved 15 May 2015)

${ }^{9}$ Seaton, 'Thanatourism', 525.

${ }^{10}$ See Phillip R. Stone and Richard Sharpley, 'Deviance, dark tourism and 'dark leisure': Towards a (re)configuration of morality and taboo in secular society,' in Contemporary Perspectives in Leisure: Meanings, Motives and Lifelong Learning ed. Sam Elkington and Sean J. Gammon, (London: Routledge, 2014), 56.

${ }^{11}$ Michael S. Bowman and Phaedra Pezzullo, 'What's so 'dark' about ‘dark tourism'?: Death, tours and performance', Tourist Studies 9, no.3 (2010): 191.

12 Avital Biran and Yaniv Poria, 'Reconceptualising dark tourism,' in The Contemporary Tourist Experiences: Concepts and Consequences eds Richard Sharpley and Phillip Stone (London: Routledge, 2012), 62.

${ }^{13}$ Biran and Poria 'Reconceptualising', 67

${ }^{14}$ Richard Sharpley, 'Shedding light on dark tourism: An introduction,' in The Darker Side of Travel: The Theory and Practice of Dark Tourism ed Richard Sharpley and Phillip R. Stone (Bristol: Channel View, 2009), 6. 
${ }^{15}$ Joy Sather-Wagstaff, Heritage that Hurts: Tourists in the Memoryscapes of September 11 (Walnut Creek: Left Coast Press, 2011), 71-72.

${ }^{16}$ Stone, 'dark tourism spectrum', 152-157.

${ }^{17}$ Phillip R. Stone, 'It's a bloody guide': Fun, fear and a lighter side of dark tourism at the dungeon visitor attractions, UK', in The Darker Side of Travel: The Theory and Practice of Dark Tourism, eds Richard Sharpley and Phillip R. Stone Bristol: Channel View, 2009), 169 ${ }^{18}$ Richard Sharpley, 'Travels to the edge of darkness: Towards a typology of 'dark tourism', in Taking Tourism to the Limits: Issues, Concepts and Managerial Perspectives eds Michelle Aicken, Stephen J. Page and Chris Ryan (Amsterdam: Elsevier, 2005), 224-226.

${ }^{19}$ Ibid, 225; Sharpley, 'Shedding light', 19; Biran and Poria 'Reconceptualising', 64.

${ }^{20}$ Diem-Trinh Thi Le and Douglas G. Pearce, 'Segmenting visitors to battlefield sites: International visitors to the former demilitarized zone in Vietnam,' Journal of Travel and Tourism Marketing 28, no.4 (2011): 461.

21 A.V. Seaton and J.J. Lennon, 'Thanatourism in the early $21^{\text {st }}$ century: Moral panics, ulterior motives and alterior desires,' in New Horizons in Tourism: Strange Experiences and Stranger Practices ed. T.V. Singh, (Wallingford: CAB International, 2004), 74,76.

${ }^{22}$ Light, Duncan, 'Dracula tourism in Romania: Cultural identity and the state,' Annals of Tourism Research 34, no.3 (2007): 757-8.

${ }^{23}$ Light, Duncan, The Dracula Dilemma: Tourism, Identity and the State in Romania, (Farnham: Ashworth: 2012), 79.

${ }^{24}$ Bram Stoker, Dracula, ed. Nina Auerbach and David Skal (New York: W.W. Norton and Company, 1997 [first published 1897]), 10.

25 Lorraine Brown, 'Tourism and pilgrimage: Paying homage to literary heroes', International Journal of Tourism Research, published online (2005): 2-3

${ }^{26}$ Stone, 'dark tourism spectrum', 152-153. 
27 Joanne Connell and Denny Meyer, 'Ballamory revisited: An evaluation of the screen tourism destination-tourist nexus’ Tourism Management 30, no.2 (2009): 194.

${ }^{28}$ Nicola Tooke and Michael Baker, 'Seeing is believing: The effect of film on visitor numbers to screened locations,' Tourism Management 17, no.2 (1996):93; Mia Larson, Christine Lundberg and Maria Lexhagen, 'Thirsting for vampire tourism: Developing pop culture destinations,' Journal of Destination Marketing and Management 2, no.2 (2013): 75.

${ }^{29}$ Emma McEvoy, 'Gothic tourism,' in The Gothic World, eds. Glynnis Byron and Dale Townsend London: Routledge, 2014), 476-486.

${ }^{30}$ Duncan Light, 'Performing Transylvania: Tourism, fantasy and play in a liminal place', Tourist Studies 9, no.3 (2009): 249.

${ }^{31}$ Stefan Roesch, The Experience of Film Location Tourists (Bristol: Channel View, 2009), 159-164; Anne Buchmann, Kevin Moore and David Fisher, 'Experiencing film tourism: Authenticity and fellowship,' Annals of Tourism Research 37, no.1 (2010):238-242.

32 Duncan Light, 'Taking Dracula on holiday: The presence of 'home' in the tourist encounter,' in The Cultural Moment in Tourism eds. Laurajane Smith, Emma Waterton and Steve Watson, (London: Routledge, 2012), 72.

${ }^{33} \mathrm{Ibid}, 74$.

${ }^{34}$ David Inglis and Mary Holmes, 'Highland and other haunts: Ghosts in Scottish Tourism,' Annals of Tourism Research 30, no.1 (2005):52-54, 56.

35 Robert S. Bristow and Mirela Newman, M. 'Myth vs. fact: An exploration of fright tourism,' in Proceedings of the 2004 Northeastern Recreation Research Symposium, edited by Kelly and Sarah .J. Millington, (Newtown Square PA: USDA Forest Service, Northeastern Research Station General Technical Report NE-326: 2005), 216. Retrieved from http://www.fs.fed.us/ne/newtown_square/publications/technical_reports/pdfs/2005/326papers /bristow326.pdf on 12 March 2008, 215. 
${ }^{36}$ Glenn W. Gentry, 'Walking with the dead: The place of ghost walk tourism in Savannah, Georgia,' Southeastern Geographer 47, no.2 (2007): 222.

${ }^{37}$ Lorri Krebbs, 'Spook tourists: We don't want 'em but they keep on coming.', Paper presented at the Association of American Geographers Annual Meeting: Chicago, 9 March 2006.

${ }^{38}$ Benjamin D'Harlingue, 'Specters of the U.S. prison regime: Haunting tourism and the penal gaze,' In Popular Ghosts: The Haunted Spaces of Everyday Culture, ed. Maria del Pillar Blanco and Esther Peeren, (New York: Continuum, 2010), 133.

${ }^{39}$ Inglis and Holmes, 'Ghosts', 51-3, 56.

${ }^{40}$ Gentry, 'Walking,' 222; Julian Holloway, 'Legend tripping in spooky spaces: Ghost tourism and infrastructures of enchantment,' Environment and Planning D: Society and Space 28, no.4 (2010):619-620; Michelle M. Hanks, Michelle, 'Re-imagining the national past: Negotiating the roles of science, religion and history in contemporary British ghost tourism.' In Contested Cultural Heritage: Religion, Nationalism, Erasure and Exclusion in a Global World, edited by Helaine Silverman, New York: Springer, 2011, 125; McEvoy, 'Gothic tourism', 480.

${ }^{41}$ Rebecca Sheehan, ‘Tourism and occultism in New Orlean's Jackson Square: Contentious and cooperative publics,' Tourism Geographies 14, no.1 (2012):81-82; Beth A.W.

Heidelberg, 'Managing ghosts: Exploring local government involvement in dark tourism,' Journal of Heritage Tourism 10, no.1 (2014): 79-82.

${ }^{42}$ Steve Pile, Real Cities: Modernity, Space and the Phantasmagorias of City Life (London: Sage, 2005),123-128.

${ }^{43}$ Karl Spracklen and Beverley Spracklen.'The strange and spooky battle over bats and black dresses: The commodification of the Whitby Goth Weekend and the loss of a subculture,' Tourist Studies 14(1): (2014): 94-6. 
${ }^{44}$ Holloway, 'Legend tripping', 626, 629.

${ }^{45}$ See Bristow and Newman, 'Myth vs. fact', 220.

${ }^{46}$ Holloway, 'Legend tripping', 618.

${ }^{47}$ Stone, 'It's a bloody guide', 173.

48 Deborah Phillips, 'Narrativised spaces: The functions of story in the theme park,' In Leisure/Tourism Geographies, ed. David Crouch (London: Routledge, 1999), 101.

${ }^{49}$ Chantal Laws, 'Pagan tourism and the management of ancient sites in Cornwall,' in Dark Tourism and Place Identity: Managing and Interpreting Dark Places eds. Leanne White and Elspeth Frew, (Routledge: London, 2013), 98.

${ }^{50}$ Oxford English Dictionary, www.oed.com (retrieved 4 May 2015).

${ }^{51}$ Sharpley, 'Travels', 220.

${ }^{52}$ Richard Sharpley, 'Tourism, religion and spirituality,' in The Sage Handbook of Tourism Studies, eds. Tazim Jamal and Mike Robinson (London: Sage, 2009), 241.

${ }^{53}$ Justine Digance, 'Religious and secular pilgrimage: Journeys redolent with meaning,' in Tourism, Religion and Spiritual Journeys, eds. Dallen J. Timothy and Daniel H. Olsen (London: Routledge), 36, 41-2, 46.

${ }^{54}$ Sharpley, 'Tourism, religion', 244; Light, 'Performing', 252.

${ }^{55}$ Sharpley, 'Travels', 225-226.

${ }^{56}$ Phillip Stone, 'Dark tourism and significant other death: Towards a model of mortality mediation', Annals of Tourism Research 39, no.3 (2012): 1565-1587.

${ }^{57}$ See Laurajane Smith, 'The cultural 'work' of tourism,' in The Cultural Moment in Tourism eds. Laurajane Smith, Emma Waterton and Steve Watson, (London: Routledge, 2012): 211215.

${ }^{58}$ See Bowman and Pezzullo, 'What's so 'dark', 199. 